\title{
KAJIAN PENETAPAN TUNJANGAN \\ PERUMAHAN KETUA DAN ANGGOTA DEWAN \\ PERWAKILAN RAKYAT DAERAH KOTA BIMA
}

\author{
Adnan $\mathcal{E}$ Nasrullah \\ Sekolah Tinggi Ilmu Hukum Muhammadiyah Bima \\ Jl. Anggrek Nomor 16 Ranggo Kel. Nae Kec. Rasa Nae Barat Kota Bima \\ Email : nasrullah@stihm-bima.ac.id
}

\section{Abstrak}

Dalam pelaksanaan penelitian tentang kajian tunjangan perumahan ketua dan anggota DPRD Kota bima dengan tujuan untuk mengetahui standar tunjagan DPRD Kota Bima. Sementara metode penelitian adalah penelitian hukum empris dengan pendekatan yang digunakan adalah pendekatan peraturan perundang-undangan, pendekatan sosiologi dan pendekatan kasus. Berdasarkan hasil menunjukan bahwa Tunjangan Perumahan Per Bulan Per Pimpinan dan Anggota DPRD Kota Bima berada pada rentang nilai : (a) Terendah : Rp. 7.019.313,-(b) Tertinggi : Rp. 11.467.500,-. Penentuan besarnya Tunjangan Perumahan mesti disusun secara rasional artinya besaran tunjangan yang dipatok betul-betul mencerminkan besar biaya sewa rumah sebagaimana kualifikasi Rumah Jabatan dan atau Rumah Dinas yang di atur bagi Pimpinan dan atau Anggota DPRD. Nilai Tunjangan perumahan Pimpinan dan anggoata DPRD Kota Bima berada pada rentang nilai tertinggi dan terendah dan Besaran untuk Ketua, Wakil Ketua dan Anggota DPRD Kota Bima dapat dipertimbangkan oleh penentu kebijakan untuk menggunakan angka atau nilai yang mencerminkan kewajaran dan kepatutan. 
Keywords: Tunjangan Perumahan; Ketua dan Anggota DPRD.

\section{Pendahuluan}

Dewan Perwakilan Rakyat Daerah selanjutnya di singkat DPRD, adalah Dewan Perwakilan Rayat Daerah sebagaimana dimaksud dalam Undang-undang Dasar Negara Republik Indonesia Tahun $1945^{1}$. Pemerintahan Daerah Provinsi, Daerah Kabupaten, dan Kota memiliki Dewan Perwakilan Rakyat Daerah yang Anggota-anggotanya dipilih melalui Pemilihan Umum². Anggota DPRD dipilih untuk mengisi jabatan dalam jangka waktu Lima Tahun. Berdasarkan Peraturan Pemerintah Nomor 24 tahun 2004 tentang Hak Keuangan dan Protokoler DPRD, gaji anggota Dewan atas lima komponen, yaitu uang representasi, tunjangan jabatan, tunjangan komunikasi, insentif, tunjangan operasional, dan tunjangan perumahan ${ }^{3}$.

Undang-undang No 27 tahun 2009 Tentang Majelis Permusyawaratan Rakyat, Dewan Perwakilan Rakyat, Dewan Perwakilan Daerah dan Dewan Perwakilan Rakyat Daerah, terakhir diganti dengan Undang-undang No 17 tahun 2014 tentang MD3 yang telah direvisi, adalah Dewan Perwakilan Rakyat Daerah merupakan Lembaga Pemerintahan Daerah sebagai wahana demokrasi dalam peneyelenggaraan pemerintahan daerah.

Sebagai lembaga pemerintahan daerah, Dewan Perwakilan Rakyat Daerah mempunyai kedudukan setara dan mempunyai hubungan kerja yang bersifat kemitraan dengan pemerintah daerah, artinya bahwa antara Dewan Perwakilan Rakyat Daerah dan Pemerintah Daerah memiliki kedudukan yang sama dan sejajar dalam arti tidak saling membawahi. Bersifat kemitraan 
berarti Dewan Perwakilan Rakyat Daerah merupakan mitra kerja Pemerintah Daerah dalam membentuk Peraturan Daerah dan membuat kebijakan daerah serta melaksanakan otonomi daerah sesuai dengan tugas dan fungsi masing-masing.

Untuk terjalinnya hubungan kerja yang harmonis dan saling mendukung diperlukan adanya pengaturan hak-hak protokoler dan keuangan bagi Pimpinan dan Anggota Dewan Perwakilan Rakyat Daerah. Hal tersebut bertujuan agar masingmasing memperoleh hak dan melaksanakan kewajiban serta meningkatkan peran dan tanggung jawab, mengembangkan kehidupan demokrasi, menjamin keterwakilan rakyat dan daerah dalam melaksanakan tugas dan kewenangannya. Mengembangkan hubungan dan mekanisme chek and balances antara lembaga legislatif dan eksekutif, meningkatkan kualitas dan produktifitas serta kinerja demi terwujudnya keadilan dan kesejahteraan rakyat.

Di dalam Peraturan Pemerintah Nomor 24 Tahun 2004 tentang Kedudukan Protokoler dan Keuangan Pimpinan dan Anggota DPRD sebagaimana diubah dengan Peraturan Pemerintah Nomor 21 Tahun 2007 tentang Perubahan Ketiga atas Peraturan Pemerintah Nomor 24 Tahun 2007, dan ditindak lanjuti oleh Surat Edaran Menteri dalam Negeri Nomor: 188.33/006/PAKD tanggal 4 januari 2006, hal : Tambahan penjelasan terhadap Peraturan Pemerintah Nomor 37 Tahun 2005 tentang perubahan atas Peraturan Pemerintah Nomor 24 Tahun 2004 tentang Kedududkan Protokoler dan Keuangan Pimpinan dan Anggota DPRD, serta Peraturan Menteri Dalam Negeri Nomor 37 Tahun 2014 tentang Pedoman Penyusunan APBD Tahun Anggaran 2015. Dan didalam Peraturan Pemerintah 
tersebut di atas, dijelaskan tentang penghasilan Pimpinan dan Anggota DPRD.

Salah satu Tunjangan Pimpinan dan Anggota Dewan Perwakilan Rakyat Daerah adalah Tunjangan Perumahan. Tunjangan Perumahan merupakan bagian dari tunjangan kesejahteraan, selain dari tunjangan perumahan Anggota DPR mendapat tunjangan kesejahteraan lainnya seperti, pemeliharaan kesehatan, kendaraaan dinas jabatan Pimpinan DPRD, dan pakain dinas. Hal ini diatur dalam Pasal 1 angka 16 Peraturan Pemerintah Nomor 24 tahun 2004 tentang Kedudukan Protokoler dan Keuangan Pimpinan dan Anggota DPRD sebagaimana diubah terakhir dengan Peraturan Pemerintah Nomor 21 Tahun 2007 tentang Perubahan Ketiga atas Peraturan Pemerintah Nomor 24 Tahun 2004, “Tunjangan Kesejahteraan adalah tunjangan yang disediakan berupa jaminan pemeliharaan kesehatan, pakaian dinas Pimpinan dan Anggota DPRD, penyediaan rumah jabatan Pimpinan DPRD dan perlengkapannya, kendaraan dinas jabatan Pimpinan DPRD, serta rumah dinas bagi Anggota DPRD dan perlengkapannya. Oleh karena Tunjangan Perumahan merupakan bagian dari tunjangan kesejahteraan maka Tunjangan Perumahan bukan merupakan penghasilan Pimpinan dan Anggota DPRD.

Memperhatikan kemampuan keuangan daerah serta kompleksitas permasalahan yang tengah dihadapi oleh Pemerintah Daerah, merupakan faktor- faktor yang mempengaruhi sehingga Pemerintah Daerah belum mampu menyediakan rumah jabatan bagi Pimpinan dan Rumah Dinas bagi Anggota Dewan Perwakilan Rakyat Daerah sebagaimana amanat Pasal 17 dan 18 Peraturan Pemerintah Nomor 24 Tahun 
2004 jo Peraturan Pemerintah Nomor 21 Tahun 2007 tentang perubahan Ketiga atas Peraturan Pemerintah Nomor 24 Tahun 2004 tentang kedudukan Protokoler dan Keuangan Pimpinan dan Perwakialan Anggota Dewan Perwakilan Rakyat Daerah.

Pada pasal 20 ayat (1) dan (2) PP No 24 Tahun 2004 tentang Kedudukan dan Protokoler di ubah dengan PP No 21 Tahun 2007 tentang Perubahan Ketiga atas PP No 24 Tahun 2004 SF Mendagri RI No 188.31/006/PAKD/Tanggal 4 Januari 2006 Hal Tambahan terhadap PP No 37 Tahun 2005 tentang perubahan dengan PP No 24 Tahun 2004 bahwa :

1. Tunjangan perumahan hanya dapat dibayarkan kepada Pimpinan dan Anggota DPRD apabila Pemerintah Daerah belum menyediakan Rumah Jabatan Pimpinan dan Rumah Dinas Anggota DPRD.

2. Pembayaran Tunjangan Perumahan setiap bulan terhitung mulai tanggal Pengucapan Sumpah Janji .

Disamping itu Pasal 10 ayat (3) dan (4) mengatur tentang pemberian Tunjangan Perumahan Pimpinan dan Anggota DPRD dan harus memperhatikan Asas Kepatutan Kewajaran dan Rasionalitas serta ketentuan besarnya tunjagan perumahan sebagaimana dimaksud pada ayat 3 dan ditetapkan dengan Peraturan Kepala Daerah.

Berdasarkan kondisi dan kemapuan keuangan tersebut dan guna menghindari perbedaan yang mencolok dalam penyediaan belanja Tunjagan Perumahan Pimpinan dan Anggota Dewan Perwakilan Rakyat Daerah Kota Bima demi terjaganya kemitraan, maka pengaturan pemberian Tunjangan Perumahan Pimpinan dan Anggota Dewan Perwakilan Rakyat Daerah Kota Bima menganut prinsip sebagai berikut : 
1. Asas Kepatutan yakni mempertimbangkan bahwa tunjangan perumahan yang diberikan kepada Anggota DPRD besarnya tidak boleh lebih besar jika dibandingkan dengan nilai rumah jabatan yang ditempati oleh pimpinan apabila disewakan. Asas kepatutan juga harus memperhatikan asas berjenjang dalam arti bahwa Tunjangan Perumahan Anggota DPRD tidak lebih besar dari tunjangan ketua DPRD, Tunjangan Wakil DPRD tidak lebih besar dari Tunjagan Ketua DPRD, Tunjangan Pimpinan dan Anggota DPRD Kabupaten/Kota tidak boleh lebih tinggi dari Tunjangan Pimpinan dan Anggota DPRD Provinsi ;

2. Asas Kewajaran yakni harus mempertimbangkan standar fisik/ konstruksi dan lokasi bangunan rumah yang layak disediakan bagi Pimpinan dan Anggota DPRD, besarnya tunjangan yang diberikan hendaknya tidak lebih besar dari harga sewa rumah yang berlaku umum untuk jenis rumah berdasarkan standar fisik/kontruksi yang ditetapkan .

3. Asas Rasionalitas yakni mempertimbangkan bahwa besarnya tunjangan perumahan yang diberikan untuk masa bhakti enam puluh bulan lebih efisien dan mengutungkan apabila membangun rumah jabatan Pimpinan DPRD dan/atau rumah dinas Anggota DPRD.

Inisiatif penepatan tunjangan perumahan Pimpinan dan Anggota Dewan Perwakilan Rakyat Daerah Kota Bima pada hakekatnya adalah merupakan respon terhadap amanat Pasal 20 Peraturan Pemerintah Nomor 37 Tahun 2005 tentang perubahan atas Peraturan Pemerintah Nomor 37 Tahun 2005 tentang Perubahan atas Peraturan Pemerintah Nomor 24 Tahun 2004 tentang Kedudukan Protokoler dan Keuangan bagi Pimpinan dan 
Anggota Dewan Perwakilan Rakyat Daerah sebagai penyesuaian terhadap Undang-undang Nomor 23 Tahun 2014 tentang Pemerintah Daerah.

Adapun permasalahan-permasalahan yang melatar belakangi usulan kenaikan tunjangan perumahan Pimpinan dan Anggota Dewan Perwakilan Rakyat Daerah untuk diakomodir dalam Peraturan Daerah tentang Anggaran Pendapatan dan Belanja Daerah Tahun 2015 antara lain:

1. Karena Nilai Jual Objek Pajak (NJOP) yang fluktuatif dan cenderung menaik, sehingga Pemerintah Daerah Kota Bima belum mampu menyediakan lahan untuk membangun Rumah Jabatan Pimpinan dan Anggota Dewan Perwakilan Rakyat Daerah sebagaimana yang di amanatkan oleh Peraturan Perundang-undangan.

2. Sesuai dengan amanat Peraturan Perundang-undangan yang mengatur kedudukan Protokoler dan Keuangan Pimpinan dan Anggota Dewan Perwakilan Rakyat Daerah, rumah jabatan Pimpinan dan Rumah Dinas Anggota Dewan Perwakilan Rakyat Daerah adalah termasuk perlengkapan, perabotan, biaya pemeliharaan rutin dan security.

3. Laju inflasi yang cenderung berubah-ubah dengan kecendrungan menaik.

Oleh karenanya perlu dilakukan penyesuaian tunjangan perumahan Dewan Perwakilan Rakyat Daerah Kota Bima pada tahun anggaran 2020, mengingat fakta lain juga menunjukkan bahwa tunjangan perumahan Dewan Perwakilan Rakyat Daerah diwilayah Nusa Tenggara Barat juga mengalami penyesuaian. Fokus permasalahan yang hendak dijawab dalam kajian ini adalah aspek ekonomi terkait berapa sebenarnya rentang besaran 
nilai Tunjangan Perumahan Dewan Perwakilan Rakyat Daerah Kota Bima yang dirasakan wajar dan patut. Disamping itu bagaimana pula dilihat dari aspek yuridis, sosiologis, maupun filosofisnya.

\section{Metode Penelitian}

Dalam kajian ini digunakan data sekunder maupun data primer. Data sekunder diperoleh melalui sumber-sumber data resmi yang diterbitkan Badan Pusat Statistik (BPS) Kota Bima dan Provinsi NTB. Sedangkan data Primer diperoleh melalui wawancara yang di pandu dengan quesioner yang akan dilakukan oleh Tim Pencari data pada beberapa lokasi pemilik rumah sewa/kost di Kota Bima. Metode kajian ini dilakukan dengan metode deskriptif analitis. Metode ini dimaksudkan bahwa pengungkapan atau menggambaran tentang keadaaan yang faktual dan akurat tentang obyek yang diamati yang dibahas secara analitis, bertitik tolak dari pemikiran, konsepsi, paradigma ataupun teori yang melandasi atau berkaitan dengan amanat aturan tentang tunjangan perumahan.

Kajian ini menggunakan asumsi dan pendekatan rumah sewa kost di Kota Bima sebagai PROXY (variabel pengganti) terhadap rumah yang dinilai memadai untuk Pimpinan dan Anggota Dewan Perwakilan Rakyat Daerah Kota Bima. Hal ini dilandasi pemikiran bahwa rumah sewa di Kota Bima belum memenuhi standar fasilitas yang memadai. Sedangkan rumah sewa kost dinilai memiliki fasilitas yang cukup memadai untuk di tempati Pimpinan dan Anggota Dewan Perwakilan Rakyat Daerah Kota Bima. Tunjangan Perumahan merupakan gabungan dari sewa rumah, iuran air, iuran telepon, rekening listrik, biaya 
cleaning service, biaya satpam, tambahan fasilitas lainnya, pajak penghasilan pasal 21 dan proyeksi inflasi Kota Bima 2020 yang fluktuatif. Jenis data yang digunkan dalam penelitian ini adalah data kuantitatif dan data kualitatif. Data yang digunakan adalah tingkat sewa dan fasilitasnya. Data primer diperoleh langsung dari pemilik rumah sewa maupun penyewa. Data sekunder diperoleh dari lembaga yang mengeluarkan data yang dibutuhkan.

\section{Hasil dan Pembahasan}

\section{Deskripsi Data-Data Nilai Sewa Rumah Kost}

Untuk memperoleh data dalam penelitian ini dilakukan dengan metode wawancara yang dipandu dengan quesioner. Tim mengirim beberapa oarang yang dilatih terlebih dahulu untuk memperoleh data yang dibutuhkan. Data tersebut antara lain yang menyangkut fasilitas rumah kost, nilai sewa tiap bulan per kamar, apa saja yang menjadi beban biaya yang ditanggung pemilik maupun penyewa setiap bulannya. Untuk memperoleh data yang baik secara statistik, maka tim menggunakan metode kuota sampling. Tiap-tiap kecamatan, jumlah rumah kost dan rumah sewanya sampai mencapai kuota minimal. Data makro menyangkut jumlah kost diperoleh dari hasil wawancara dengan aparat kelurahan dan kecamatan.

Beberapa kendala yang dihadapi adalah adanya keengganan dari pemilik rumah kost untuk memberikan data yang benar. Hal ini dapat dimaklumi mengingat sebagian pemilik rumah kost umumnya menghindari adanya pajak atau retribusi yang harus disetor kepada pemerintah menyangkut kepemilikan usahanya. Akan tetapi dengan memberikan 
pengertian atas tujuan dan maksud survey, baru mereka berbicara dan memberikan data secara terbuka dengan catatan nama dan identitasnya dirahasiakan.

Hasil suvey yang dilakukan selama kurang lebih sebulan, akhirnya diperoleh data yang menurut hemat kami selaku tim dapat dipertanggungjawabkan. Berdasarkan hasil survey yang dilakukan oleh tim secara sampling pada beberapa wilayah Kecamatan di Kota Bima, yaitu Kecamatan Mpunda, Raba, RasanaE Barat, RasanaE Timur dan Asa Kota di peroleh data sebagaimana tersaji pada tabel 3. 1 berikut :

Tabel 3.1

Hasil survei terhadap Nilai Sewa Rumah Tinggal (Kost) Per Bulan

Per kamar di Kota Bima

\begin{tabular}{|c|c|c|c|c|c|}
\hline \multirow{2}{*}{ No } & \multirow{2}{*}{$\begin{array}{l}\text { Pemilik } \\
\text { Kost }^{*}\end{array}$} & \multirow{2}{*}{$\begin{array}{l}\text { Kecamatan } \\
\text { yang di survei }\end{array}$} & \multicolumn{3}{|c|}{$\begin{array}{l}\text { Rerata Sewa per kamar } \\
\text { (Rp.000,-per bulan) }\end{array}$} \\
\hline & & & Terendah & Tertinggi & Rerata \\
\hline 1 & $\mathrm{Aa}$ & Mpunda & \multirow{7}{*}{425} & \multirow{7}{*}{1.500} & \multirow{7}{*}{962,5} \\
\hline 2 & $\mathrm{Bb}$ & Mpunda & & & \\
\hline 3 & Cc & Mpunda & & & \\
\hline 4 & $\mathrm{Dd}$ & Mpunda & & & \\
\hline 5 & Ee & Mpunda & & & \\
\hline 6 & $\mathrm{Ff}$ & Mpunda & & & \\
\hline 7 & $\mathrm{Gg}$ & Mpunda & & & \\
\hline
\end{tabular}

Sangaji Jurnal Pemikiran Syariah dan Hukum 
Kajian Penetapan Tunjangan Perumahan Ketua dan Anggota... $\mid 223$

\begin{tabular}{|c|c|c|c|c|c|}
\hline 8 & $\mathrm{Hh}$ & Rasanae Barat & \multirow{5}{*}{450} & \multirow{5}{*}{2.350} & \multirow{5}{*}{1.400} \\
\hline 9 & Ii & Rasanae Barat & & & \\
\hline 10 & $\mathrm{Jj}$ & Rasanae Barat & & & \\
\hline 11 & $\mathrm{Kk}$ & Rasanae Barat & & & \\
\hline 12 & $\mathrm{Ll}$ & Rasanae Barat & & & \\
\hline 13 & $\mathrm{Mm}$ & $\begin{array}{l}\text { Rasanae } \\
\text { Timur }\end{array}$ & \multirow{4}{*}{400} & \multirow{4}{*}{1.350} & \multirow{4}{*}{875} \\
\hline 14 & $\mathrm{Nn}$ & $\begin{array}{l}\text { Rasanae } \\
\text { Timur }\end{array}$ & & & \\
\hline 15 & Oo & $\begin{array}{l}\text { Rasanae } \\
\text { Timur }\end{array}$ & & & \\
\hline 16 & $\mathrm{Pp}$ & $\begin{array}{l}\text { Rasanae } \\
\text { Timur }\end{array}$ & & & \\
\hline 17 & $\mathrm{Qq}$ & Raba & \multirow{6}{*}{350} & \multirow{6}{*}{850} & \multirow{6}{*}{600} \\
\hline 18 & $\mathrm{Rr}$ & Raba & & & \\
\hline 19 & Ss & Raba & & & \\
\hline 20 & $\mathrm{Tt}$ & Raba & & & \\
\hline 21 & Uu & Raba & & & \\
\hline 22 & Vv & Raba & & & \\
\hline 23 & Ww & Asakota & & & \\
\hline 24 & $X x$ & Asakota & & & \\
\hline
\end{tabular}




\begin{tabular}{|c|c|l|l|l|l|}
\hline 25 & Yy & Asakota & & & \\
\cline { 1 - 3 } 26 & $\mathrm{Zz}$ & Asakota & & & \\
& & & & \\
27 & $\mathrm{Ab}$ & Asakota & & & \\
\hline 28 & Ac & Asakota & & & \\
\hline 29 & Ad & Asakota & & & \\
\hline 30 & Ae & Asakota & & & \\
\hline
\end{tabular}

Sumber : data hasil survey (primer di olah); *nama pemilik kost diberi kode

Data diperoleh dengan menggunakan cluster sampling. Penyebaran wilayah juga dibagi dengan sistem wilayah cluster sampling. Berdasarkan populasi dari rumah kost yang tercatat. Untuk efisiensi waktu, maka digunakan prinsip pengambilan sampel dengan 2,5\% dari total populasi (Sugiono, 2003)

Dari data pada tabel 3. 1. Terlihat bahwa paling rendah sewa rumah kost yang standar adalah Rp. 350.000,- per bulan per kamar, kecuali Kecamatan RasanaE Barat sebesar Rp 450.000,- per bulan per kamar. Sedangkan tarif sewa tertinggi sebesar Rp. 2 350.000,- juga tercatat di Kecamatan RasanaE Barat.

Dengan demikian, rata-rata sewa per kecamatan adalah sebagai berikut :

a) Kecamatan Mpunda Rp. 962.500,-

b) Kecamatan RasanaE Barat Rp. 1.400.000,- 
c) Kecamatan RasanaE Timur

Rp. 875.000,-

d) Kecamatan Raba

Rp. 600.000,-

e) Kecamatan Asakota

Rp. 850.000,-

Dengan demikian, rata-rata sewa kost per kamar berada dalam rentang Rp. 600.000,- sampai Rp. 1.400.000,- per bulan per kamar.

Untuk memudahkan analisa dengan rentang sewa tersebut, maka di buat kelas :

a) Rendah

b) Sedang

c) Tinggi

Untuk memudahkan penetapan kelas, maka kelas di bagi 3 yaitu : rendah, sedang dan tinggi. Bila di urut nilainya, maka deretan rata-rata lima kecamatan adalah sebagai berikut : $600,850,875,962,5,1.400$

Tabel 3.2. Penetapan Rentang Nilai Sewa Rumah Kost Berdasarkan Tiga Kategori

\begin{tabular}{|c|c|c|c|}
\hline Interval & Nilai Tengah & Kategori & $\begin{array}{c}\text { Kualifikasi } \\
\text { Rumah Sewa }\end{array}$ \\
\hline $525-750$ & 637,5 & Rendah & Biasa \\
\hline $751-976$ & 863,5 & Sedang & Standar \\
\hline $977-1.310$ & $1.189,5$ & Tinggi & Mewah \\
\hline
\end{tabular}

\section{Sumber : data primer (di olah)}

Berdasarkan data di atas, maka dengan sendirinya yang diharapkan adalah bahwa tunjangan perumahan Pimpinan 
dan Anggota DPRD harus memenuhi syarat tidak mewah, tetapi juga tidak semestinya di bawah standar. Oleh karenanya, maka tarif sewa yang dinilai wajar per kamar adalah berada pada rentang Rp.850.000,- sampai Rp. 1.076.000,-

Untuk mengoreksi batas atas kategori sedang atau standar, maka batas atas yang lebih wajar adalah Rp. 1.050.000,-. Hal ini harus dilakukan mengingat nilai rata-rata data sewa tertinggi adalah Rp. 1.500.000,- sementara dalam interval pada kategori tinggi adalah Rp. 1. 310.000,--

\section{Hasil Survey Tarif Kebutuhan Lain Rumah Sewa yang menjadi Beban tetap Penyewa}

Hasil survey menunjukan bahwa seluruh rumah sewa di bebaskan dari pembayaran iuran listrik setiap bulannya. Adapun iuran air, telepon/fax, maupun iuran sampah/ kebersihan atau keamanan seluruhnya ditanggung oleh penyewa.

Adapaun yang diperoleh untuk kebutuhan iuran air, telepon/fax, maupun iuran kebersihan dan keamanan sebagai berikut :

Kebutuhan Lain Rumah Sewa Kota Bima

\begin{tabular}{|l|l|l|}
\hline No & Jenis Kebutuhan & Rata-rata \\
\hline 1 & Listrik/Air & $825.000,-$ \\
\hline 2 & Telepon/fax & $400.000,-$ \\
\hline 3 & Kebersihan, Keamanan/Satpam & $1.550 .000,-$ \\
\hline
\end{tabular}

Sumber data yang di olah

Daya beli dan pendapatan riil menjadi syarat kesejahteraan seseorang. Sejak tahun 2010, Kota Bima telah

Sangaji Jurnal Pemikiran Syariah dan Hukum 
menjadi salah satu Kota di Indonesia yang menjadi rujukan perhitungan Inflasi. Bahkan untuk ukuran Provinsi Nusa Tenggara Barat termasuk kedua setelah Kota mataram. Hal ini menunjukan bahwa jenis dan ragam barang dan jasa sudah cukup banyak beredar di Kota Bima dibandingkan Kota lainya di Nusa Tenggara Barat.

Berdasarkan Data selama 2012 - 2014 per April Inflasi Kota Bima adalah sebagai berikut:

Tabel 3.4. Perkembangan Inflasi di Kota Bima (2010 - 20014)

\begin{tabular}{|c|c|c|}
\hline Tahun & Rata-rata\% & Keterangan \\
\hline 2010 & 4,53 & $\begin{array}{c}\text { Sumber Bapepeda Prov } \\
\text { NTB }\end{array}$ \\
\hline 2011 & 4,09 & Proyeksi \\
\hline 2012 & 4,53 & \\
\hline 2013 & 5,89 & Proyeksi \\
\hline $2014^{*}$ & 5,00 & Ekonom Pembab \\
\hline
\end{tabular}

Sumber: BPS Kota Bima * Proyeksi Tim Ekonomi Pembkab bima

\section{a) Pengitungan Tunjangan Perumahan}

Dengan Asumsi tidak terdapat perbedaan yang signifikan antara pimpinan dan anggota DPRD, maka sewa kost per kamar berdasarkan nilai wajar yang disuvei disertakan atau dikonversikan ke dalam 5 kamar, 3 kamar tidur, 1 kamar tamu dan 1 kamar keluarga dengan dua orang anak sesuai ketentuan yang berlaku. Maka perhitungannya adalah sebagai berikut: 
b) Komponen Pembentuk Tunjangan Perumahan

Mengingat secara umum sewa kost yang di survei umumnya membebankan pembayaran listrik, air telepon dan fasilitas tambahan lainnya kepada penyewa, maka besaran Tunjangan Perumahan yang wajar per bulan sebagai berikut :

\section{Batas Tertinggi}

A. Komponenen Biaya yang dikeluarkan untuk Rumah Secara Langsung

1. Sewa bangunan (5 kamar @Rp. 1.400.000)Rp. 7.000.000,-

2. Iuran Air/listrik Rp. 825.000,-

3. Iuran telepon/fax Rp. 400.000,-

4. Upah Tenagan Cleaning Service Tetap, Rangkap satpam dan Asisten administrasi...Rp. 1.550.000,-

5. Tambahan fasilitas lainnya Rp. 650.000,Total Rp. 10.425.000,-

B. Tunjangan Pajak Penghasilan Pasal 21 atas Tunjangan Perumahan sebesara $15 \%$. Rp. 1.563.000,Sub Total A + B Rp. 11.988.750,-

C. Inflasi atas Dasar Indeks Harga Konsumen 
Kota Bima (5\%) Rp.

521.250,-

Total Tunjangan Perumahan Rp. 11.467.500,-

\section{Batas terendah}

A. Komponen Biaya yang dikeluarkan untuk Rumah secara Langsung

1. Sewa bangunan (5 kamar @ Rp. 850.000)..Rp. 4.250.000,-

2. Iuran air/listrik.Rp. 450.000 ,

3. Iuran telepon/fax.Rp. 300.000,-

4. Upah tenaga Cleaning Service tetap, rangkap satpam dan administras Rp. 1.000.000,-

5. Tambahan fasilitas lainnya...Rp. 425.000,-Total Rp.

6.425.000,-

B. Tunjangan pajak pengahasilan pasal 21 atas tunjangan Perumahan sebesar 15\%...Rp. 963.750,Sub Total A + B.Rp. 7.388.750,-

C. Inflasi atas dasar indeks Harga Konsumen Kota Bima (5)\%... Rp. 369.437,-Total Tunjangan Perumahan Rp. 7.019.313,-

Menurut konfirmasi langsung besaran tunjagan perumahan Pimpinan dan Anggota DPRD Provinsi NTB Tahun 2012 sebesar :

1. Ketua DPRD Provinsi NTB sebesar Rp. 10.000.000,-

2. Wakil Ketua DPRD Provinsi NTB sebesar Rp. 9.500.000,- 
3. Anggota DPRD Provinsi NTB sebesar Rp. 9.000.000,-

Sedangkan rencana sekarang menurut konfirmasi langsung bahwa dalam rancangan dinaikkan menjadi maksimal sebesar Rp. 13.000.000,-

\section{Kajian Sosilogis}

Manusia merupakan zoonpoloticon bagi manusia lainnya, dalam kehidupan sosial masyarakatan setiap orang tertentu saling berbagi dan saling memberi antara satu dengan yang lainnya. Hal tersebut tentu saja akan terjadi apabila tingkat kesejahteraan seseorang lebih mapan dari yang lainnya, sebab tingkat kesejahteraan menjadi modal utama bagi seseorang dalam melakoni kehidupan sosialnya.

Demikian halnya dengan Pimpinan dan Anggota dewan Perwakilan Daerah Kota Bima dalam melaksanakan tugas dan fungsi-fungsinya sebagai pengawas pemerintah daerah akan bekerja dengan maksimal apabila kesejahteraan mereka diperhatikan.

Selama ini DPRD memang telah melakukan berbagai konsultasi publik dalam proses penentuan anggaran derah sesuai dengan batas-batas kewenangannya, tetapi walaupun DPRD telah melakukannya dengan sungguh-sungguh, masyarakat umum masih mengkritik berbagai ketidak beresan dalam proses penganggaran.

Perumusan kebijakan baru dalam proses penganggaran di DPRD memperhatikan beberapa konteks umum, Pertama, DPRD memperhatikan kepentingan masyarakat umum secara optimal, sebab DPRD harus menyeimbangkannya dengan kepentingan partai politik dan kelompok-kelompok strategis 
yang telah memberikan dukungan kepadanya selam proses pemilihan. Optimalisasi akomodasi kepentingan rakyat ini terkait langsung dengan kapasitas dan partisipasi masyarakat dalam proses penganggaran.

Kedua, DRPD perlu mempunyai kapasitas formulasi dan singkronisasi kebijakan pemerintahan dan pembangunan yang terkait dengan penganggaran di daerah. Tampa kapasitas tersebut DPRD sulit untuk memberikan evaluasi dan persetujuan secara mapan terhadap anggaran yang disampaikan oleh pemerintah daerah, dengan kata lain penjelasan tentang lingkup dan norma-norma prosedural sangat diperlukan oleh DPRD agar tidak melakukan kekeliruan yang tidak perlu, sebab struktur dan proses pembiayaan di daerah sangat kompleks.

ketiga, DPRD perlu membangun pemahaman bahwa proses penganggaran bukan hanya upaya untuk menyeimbangkan Cash flow dari APBD lebih-lebih itu dalam paradigma demokratic govermance, penganggaran merupakan proses politik yang mempertemukan kebutuhan masyarakat dengan kapasitas dan upaya alokasi financial yang dimiliki oleh Pemerintah Daerah. Dalam konteks itulah, kualitas sejahteraan para legislator menjadi salah satu pilihan sehingga kedepan mereka dapat menuangkan pemikiran-pemikiran yang konstruktif dalam mengkondisikan produk-produk hukum didaerah sehingga regulasi yang dihasilkan menjadi lebih berkualitas dalam rangka upaya mensejahterakan seluruh masyarakat di Kota Bima. 


\section{Kajian Filosofis}

Berbagai pengalaman menunjukan bahwa sangatlah sulit bagi masyarakat umum dan DPRD yang mempunyai hak budget untuk terlibat secara aktif dalam penyusunan anggaran. Masyarakat umum harus menghadapi berbagai hambatan untuk beradaptasi riil atau untuk mendapatkan dokumen APBD, padahal partisipasi masyarakat adalah merupakan unsur terpenting dalam proses pembangunan dan mengembangkan proses membangun dan mengembangkan sistim pemerintahan yang lebih aspiratif dan demokratis.

Sesuai dengan amanat Undang-undang Dasar Negara Republik Indonesia Tahun 1945, Pemerintah Daerah berwenang mengatur dan mengurus rumah tanggganya sendiri menurut asas otonomi dan medebewind. Pemberian otonomi seluas-luasnya kepada daerah bertujuan pada peningkatan peran serta dan prakarsa yang bertujuan pada peningkatan kesejahteraan masyarakat. Hal tersebut tercermin dalam perubahan Peraturan Pemerintah Nomor 32 tahun 2004, disamping karena adanya Undang-undang Nomor 32 Tahun 2004 dan beberapa penetapan kebijakan dalam penyelenggaraan otonomi daerah.

\section{Simpulan}

Berdasarkan hasil pembahasan diatas dapat ditarik kesimpulan bahwa besaran Tunjangan Perumahan Per Bulan Per Pimpinan dan Anggota DPRD Kota Bima berada pada rentang nilai : (a) Terendah : Rp. 7.019.313,-(b) Tertinggi : Rp. 11.467.500,-Penentuan besarnya Tunjangan Perumahan mesti disusun secara rasional artinya besaran tunjangan yang dipatok betul-betul 
mencerminkan besar biaya sewa rumah sebagaimana kualifikasi Rumah Jabatan dan atau Rumah Dinas yang di atur bagi Pimpinan dan atau Anggota DPRD. Sementara Nilai Tunjangan perumahan Pimpinan dan anggoata DPRD Kota Bima berada pada rentang nilai tertinggi dan terendah dan Besaran untuk Ketua, Wakil Ketua dan Anggota DPRD Kota Bima dapat dipertimbangkan oleh penentu kebijakan untuk menggunakan angka atau nilai yang mencerminkan kewajaran dan kepatutan. 


\section{DAFTAR PUSTAKA}

Marco,Larisa, 2008, Determinantsof New York City Reseindential Rental Prices, Wangsinton University in St Louis, USA. Download tanggal 15 desember 2001

Peraturan Pemerintah Republik Indonesia Nomor 24 Tahun 2004 Tentang Kedudukan Protokoler dan Keuangan Pimpinan dan Anggota Dewan Perwakilan Rakyat Daerah

Peraturan Pemerintah Republik Indonesia nomor 37 Tahun 2006 Tentang perubahan Kedua atas Peraturan Pemerintah Republik Indonesia Nomor 24 Tahun 2004 Tentang Kedudukan Protokoler dan Keuangan Pimpinan dan Anggota Dewan Perwakilan Rakyat Daerah

Peter A.Kemp, 2008, A comparative Study Of Housing Allowances, A reportof research carried out by the Centre for Housing Research and Urban Studies University of Glasgow, on behalf of the Departement of Social Security, London UK. Download tanggal 12 desember 2011

Simamora, Henr,2004,manajemen Sumber Daya Manusia, Bina Aksara, Jakarta

Sugiyono,2007, Metodologi Penelitian Administrasi, alfabeta, Bandung

Surat Edaran Menteri Tenaga Kerja No.SE-07/Men/1990 tentang Pengelompokan Upah dan Pendapatan Non Upah Undang-undang (UU) No 13 tahun 2003 tentang Tenaga Kerja

Sangaji Jurnal Pemikiran Syariah dan Hukum 